\title{
Communication and leadership in emergency situations: Systematic literature review and recommendations for practice
}

José Carlos Amado Martins, Ana Catarina Vaz de Sousa, Ana Rita Diogo Abrantes, Catarina Sofia da Silva Pinto, Cristiana Isabel de Almeida Gomes, Daniel José Oliveira Martins, Verónica Rita Dias Coutinho, Rui Carlos Negrão Baptista, Luís Miguel Nunes de Oliveira, Maria Isabel Domingues Fernandes

Nursing School of Coimbra, Coimbra, Portugal

Received: October 22, 2017

Accepted: December 7, 2017

Online Published: December 18, 2017

DOI: $10.5430 /$ cns.v6n2p55

URL: https://doi.org/10.5430/cns.v6n2p55

\begin{abstract}
Background: Communication and leadership are two interconnected concepts that are essential to achieving successful and high-quality team interventions in emergency situations.

Objective: To identify communication and leadership best practices in emergency situations.

Methods: A systematic literature review with meta-synthesis was conducted using the Joanna Briggs Institute (JBI) Reviewers' Manual (JBI, 2014). A search was conducted to identify studies published between January 2006 and July 2016 using the terms communication, leadership, and emergency. Studies in the areas of pediatrics or simulated practice environments were excluded. Results: Nineteen of the 447 studies found in the search met the inclusion criteria. During synthesis, data were divided into three dimensions: leader's characteristics, initial and lifelong training, and leadership process. Communication and leadership training were considered essential for developing skills required in emergency situations.

Conclusions: Despite the low level of evidence of the included studies, this study puts forward recommendations for communication and leadership best practices in emergency situations.
\end{abstract}

Key Words: Communication, Leadership, Emergency, Emergency care, Health care team, Best practices

\section{INTRODUCTION}

Effective communication and leadership are essential in emergency responses, ensuring better health outcomes and increasing patient safety. ${ }^{[1-3]}$

The existing literature on communication and leadership in emergency situations has not yet been systematically reviewed and, for this reason, the current recommendations are scattered and lack evidence.

In 2010, a systematic review ${ }^{[1]}$ included studies published between 2002 and 2008, but it only addressed teamwork and communication in an emergency department and did not produce recommendations. In 2014, a systematic review ${ }^{[2]}$ analyzed aspects related to leadership and communication, but from the perspective of older people admitted to the emergency department.

This systematic literature review (SLR) aimed to identify communication and leadership best practices in emergency situations with the purpose of producing evidence-based recommendations for practice.

*Correspondence: José Carlos Amado Martins; Email: jmartins@esenfc.pt; Address: Nursing School of Coimbra, Coimbra, Portugal. 
In this paper, the term "emergency situations" includes all the situations that demand multidisciplinary teamwork, as well as advanced and differentiated technical resources to support life, in emergency departments or other clinical settings.

Communicating means "to put something in common" by using a set of strategies used to share a message. The first axiom of human communication states that one cannot not communicate, so when two or more people interact, everything is communication. This study is particularly interested in verbal and intentional communication during teamwork in critical events.

Leading means "to guide or direct", "to go at the head of or have the top position in", and good leadership in health is a prerequisite for a more efficient and effective care delivery. ${ }^{[3]}$

Effective communication and leadership are key components in health care quality, particularly when a team needs to provide a timely and organized response in emergency situations. ${ }^{[4]}$

Effective leadership is associated with improved teamwork outcomes in emergency situations ${ }^{[5-7]}$ and improved staff engagement. ${ }^{[8]}$

Emergency situations are often characterized by high complexity, uncertainty, chaos, and ambiguity, ${ }^{[9]}$ thus requiring a coordinated and synchronized collective action. ${ }^{[4,7]}$

Health professionals' training should include the development of teamwork skills and assign equal importance to the acquisition of knowledge (know-how), relational/ethical skills, and technical skills. ${ }^{[4,10]}$ Several communication strategies have been used in different areas and contexts. One of the most widely used strategies is SBAR (Situation, Background, Assessment, and Recommendation), ${ }^{[1]}$ which allows ensuring that all team members understand their role and the action plan, thus contributing to a true teamwork. ${ }^{[6]}$ The SBAR strategy can be described as follows:

S - To draw the team's attention to an emergency situation.
B - To share with the team the most relevant information about the critically ill patient.

A - To share with the team any relevant information that helps to find the underlying cause of the emergency or possible injuries.

$\mathrm{R}$ - To assign tasks to team members, naming the task and the person who should perform it.

This study aims to identify communication and leadership best practices in an emergency situation.

\section{Methods}

This SLR was conducted based on the recommendations found in the Joanna Briggs Institute (JBI) Reviewers' Manual (JBI, 2014). ${ }^{[12]}$ A detailed protocol was elaborated for the SLR, but it was not recorded. The following research question was formulated: What is the evidence on effective team communication and leadership in an emergency situation?

An initial search was performed to define the search terms, in Portuguese and English and their adequacy to the different databases. A database search was subsequently performed using these terms and some limiters in July 2016.

The following articles were excluded: studies conducted in pediatric and simulated practice environments, studies conducted in emergency departments without a specific focus on leadership and communication and their association with emergency situations, and studies conducted in non-clinical emergency situations (e.g., fires and earthquakes). Editorials, letters to the editor, and abstracts for presentation in scientific events were also excluded. All other relevant articles were included.

The search was limited by language and date of publication, thus including articles written in English or Portuguese and published between January 2006 (the year when the first studies on the topic were published) and July 2016. Table 1 shows the search strategy.

Table 1. Search strategy

\begin{tabular}{ll}
\hline Database & Search formula \\
\hline - Psychology and Behavioral Sciences Collection & \\
- MEDLINE & \\
- CINAHL plus & (Communication) AND (Leadership) AND \\
- MedicLatina & (Emergency) NOT (AB: Pediatrics) NOT (AB: \\
- Academic Search Complete & Simulation Training) \\
$\begin{array}{l}\text { - ERIC } \\
\text { - SCIENCE DIRECT }\end{array}$ & \\
$\begin{array}{l}\text { - COCHRANE } \\
\text { - SciELO }\end{array}$ & \\
- INDECS & Comunicação AND Liderança AND Emergência \\
- RCAAP & \\
\hline
\end{tabular}


2.1 Assessment of the methodological quality of the studies

Two independent reviewers analyzed the methodological quality of the articles using different JBI tools: the JBI Critical Appraisal Checklist for Descriptive/Case Series (9 items) for observational studies; the JBI QARI Critical Appraisal Checklist for Interpretative and Critical Research (10 items) for qualitative studies; and the JBI Critical Appraisal Checklist for Narrative, Expert Opinion \& Text (7 items) for theoretical or opinion articles.

Studies that did not comply with two or more items (answer "no" or "unclear") in the corresponding methodological quality appraisal tool were excluded.

The critical appraisal demonstrated the high methodological quality of the included studies. However, there was a risk of bias due to the study design, particularly in the case of qualitative studies, integrative reviews, and theoretical reviews.

\subsection{Data extraction}

Two independent reviewers extracted the data using the data extraction matrix designed by the authors for this purpose.

The reviewers reached a consensus in most of the critical appraisals. Any disagreements between the reviewers were resolved through discussion with a third reviewer.

\subsection{Data synthesis}

Since no experimental studies were found, data were grouped in a narrative format and synthesized with a view to producing recommendations.

\section{Results}

A total of 447 potentially relevant studies were identified; however, only 19 studies were included in this SLR. Upon analysis and application of the inclusion criteria, 13 records were eliminated for being duplicates, 346 studies were excluded after title analysis, 67 after abstract analysis, and five after full-text analysis. Figure 1 summarizes the study selection process.

Most of the studies used qualitative methods (11) and were conducted in the United Kingdom (5). Table 2 shows the included studies and the corresponding methodological quality.

Qualitative studies used semi-structured interviews for data collection. In addition, studies 1, 3, 13, and 14 used an observation grid to assess practices. Studies 7, 8, 10, and 11 used questionnaires for data collection.

Tables 3, 4, and 5 show the results divided into three dimensions: leader's characteristics, initial and lifelong training, and leadership process. In each table, the checkmark indicates that the study considered the corresponding results as specific outcomes.

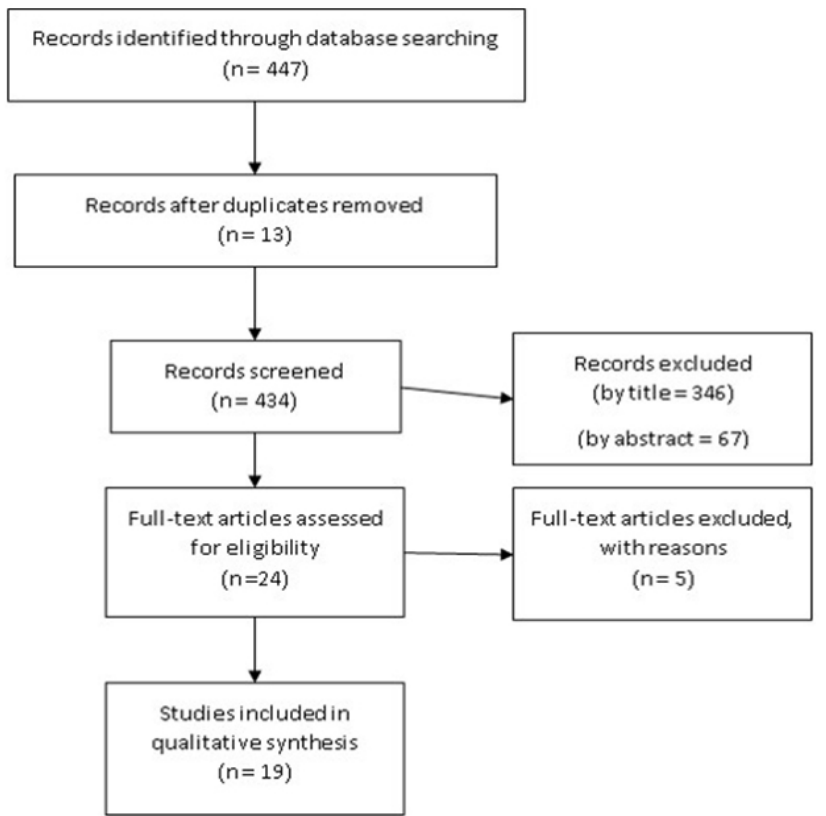

Figure 1. Review process

\section{Discussion}

Emergency settings are characterized by multiple specificities related to complex situations, unexpected events, uncertainty, and time pressure, among others. ${ }^{[9,28]}$ For this reason, teams must be continuously prepared ${ }^{[28]}$ and able to rely on effective leadership and communication. ${ }^{[5-8,26]}$ However, there is often a lack of leadership education and training. ${ }^{[14,15]}$

Both teams and leaders need continuous education and training in order to gain proficiency and scientific knowledge, as well as technical, relational, and ethical skills. Almost all studies included in this SLR mention the importance of communication, leadership, and teamwork training. ${ }^{[4,5,11,13,16,18,22,24-26,29]}$ Simulation-based training is an important pedagogical tool to consolidate knowledge, ${ }^{[30,31]}$ develop acute care skills, maintain proficiency, ${ }^{[30,32-34]}$ and produce leaders. ${ }^{[35-39]}$

Communication and leadership are two closely related concepts, ${ }^{[13]}$ to the extent that effective leadership requires effective communication ${ }^{[4,10,11,19,24,26]}$ at different levels: to collect and process data; ${ }^{[14]}$ to make quick ${ }^{[13,22]}$ and correct decisions; $;^{[16,19,22]}$ to achieve a more effective teamwork $;^{[13,17,23,25]}$ to motivate the team; ${ }^{[14]}$ to improve the overall quality of the response; ${ }^{[4,14,15,20,24,29]}$ and to improve patient safety. ${ }^{[4,13-15,18,19,22,24]}$ 
Table 2. Studies included in this review

\begin{tabular}{|c|c|c|c|c|c|c|c|}
\hline \multirow{2}{*}{ Study } & \multirow{2}{*}{ Author (year) } & \multirow{2}{*}{ Country } & \multirow{2}{*}{ Type of study } & \multirow{2}{*}{ Sample(s) } & \multicolumn{3}{|c|}{ Quality assessment } \\
\hline & & & & & Yes & No & Unclear \\
\hline 1 & Montezeli et al. (2013) ${ }^{[13]}$ & Brazil & Qualitative & 8 nurses & 8 & 1 & 1 \\
\hline 2 & Linton and Farrell (2009) ${ }^{[14]}$ & Australia & Qualitative & 6 nurses & 9 & 1 & 0 \\
\hline 3 & Cole and Crichton (2006) ${ }^{[15]}$ & UK & Qualitative & 11 emergency professionals & 9 & 1 & 0 \\
\hline 4 & Andersen et al. $(2010)^{[6]}$ & Denmark & Qualitative & 11 ALS instructors & 8 & 2 & 0 \\
\hline 5 & Cathcart et al. (2010) ${ }^{[16]}$ & USA & Qualitative & 32 nurses & 8 & 2 & 0 \\
\hline 6 & Araszewski et al. (2014) ${ }^{[17]}$ & Brazil & Qualitative & 9 nurses & 9 & 0 & 1 \\
\hline 7 & Price et al. (2012) ${ }^{[11]}$ & Canada & Observational & $\begin{array}{l}49 \text { nurses } \\
19 \text { physicians }\end{array}$ & 7 & 1 & 1 \\
\hline 8 & Clements et al. (2015) ${ }^{[18]}$ & Australia & $\begin{array}{l}\text { Observational } \\
\text { pre-post test }\end{array}$ & 24 nurses & 8 & 1 & 0 \\
\hline 9 & Flowerdew et al. (2012) ${ }^{[10]}$ & UK & Qualitative & $22 \mathrm{ED}$ professionals & 8 & 0 & 1 \\
\hline 10 & Cooper et al. $(2007)^{[19]}$ & UK & Mixed & $\begin{array}{l}24 \text { professionals observed } \\
45 \text { professionals interviewed } \\
611 \text { clinical records (audit) }\end{array}$ & 7 & 1 & 1 \\
\hline 11 & Kemper et al. (2013) ${ }^{[20]}$ & Netherlands & Observational & $\begin{array}{l}378 \text { ED professionals } \\
1,144 \text { ICU professionals }\end{array}$ & 7 & 1 & 1 \\
\hline 12 & Deitchman (2013) ${ }^{[21]}$ & USA & $\begin{array}{l}\text { Theoretical } \\
\text { review }\end{array}$ & 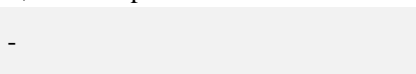 & 6 & 0 & 1 \\
\hline 13 & Leach and Mayo (2013) ${ }^{[22]}$ & USA & Qualitative & $\begin{array}{l}9 \text { professionals observed } \\
17 \text { professionals interviewed }\end{array}$ & 10 & 0 & 0 \\
\hline 14 & Speck et al. (2012) ${ }^{[23]}$ & USA & Qualitative & $\begin{array}{l}32 \text { ( } 8 \text { nurses, } 7 \text { medicine students, } 4 \\
\text { grant holders, } 13 \text { team leaders) }\end{array}$ & 8 & 1 & 1 \\
\hline 15 & Silva et al. (2014) ${ }^{[24]}$ & Brazil & $\begin{array}{l}\text { Integrative } \\
\text { literature review }\end{array}$ & 12 articles & 7 & 0 & 0 \\
\hline 16 & Azinhaga $(2014)^{[4]}$ & Portugal & Qualitative & 12 (6 physicians, 6 nurses) & 8 & 0 & 1 \\
\hline 17 & Manser (2009) ${ }^{[25]}$ & Switzerland & $\begin{array}{l}\text { Theoretical } \\
\text { review }\end{array}$ & 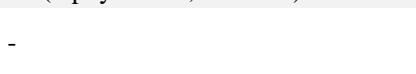 & 7 & 0 & 0 \\
\hline 18 & Bristowe et al. (2012) ${ }^{[26]}$ & UK & Qualitative & 28 physicians & 9 & 1 & 0 \\
\hline 19 & Lynch and Cole (2006) ${ }^{[27]}$ & UK & Expert Opinion & - & 7 & 0 & 0 \\
\hline
\end{tabular}

Table 3. Results: Leader's characteristics

\begin{tabular}{|c|c|c|c|c|c|c|c|c|c|c|c|c|c|c|c|c|c|c|c|}
\hline \multirow{2}{*}{ Results } & \multicolumn{19}{|c|}{ Study } \\
\hline & 1 & 2 & 3 & 4 & 5 & 6 & 7 & $\mathbf{8}$ & 9 & 10 & 11 & 12 & 13 & 14 & 15 & 16 & 17 & 18 & 19 \\
\hline Experience & $\sqrt{ }$ & $\sqrt{ }$ & $\sqrt{ }$ & $\sqrt{ }$ & & $\sqrt{ }$ & & $\sqrt{ }$ & & $\sqrt{ }$ & & . & & 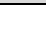 & $\sqrt{ }$ & $\sqrt{ }$ & $\sqrt{ }$ & $\sqrt{ }$ & $\sqrt{ }$ \\
\hline Leads by example & & $\sqrt{ }$ & & & $\sqrt{ }$ & & & & & & & & & & & & & & $\sqrt{ }$ \\
\hline Self-confidence & & $\sqrt{ }$ & & & & & & & & & & $\sqrt{ }$ & & $\sqrt{ }$ & & & & $\sqrt{ }$ & \\
\hline Critical thinking & & $\sqrt{ }$ & & & & & & & & & & & & & & & & & \\
\hline Communicates effectively & & & & $\sqrt{ }$ & & & & & & & & $\sqrt{ }$ & & & & & $\sqrt{ }$ & $\sqrt{ }$ & $\sqrt{ }$ \\
\hline Knows the team & & $\sqrt{ }$ & & & & & & & & & & & & & & & $\sqrt{ }$ & & \\
\hline Encourages others & & $\sqrt{ }$ & & & & & & & & & & & & & & & & & $\sqrt{ }$ \\
\hline Respects others & & $\sqrt{ }$ & & & & & & & & & & & & $\sqrt{ }$ & & & & $\sqrt{ }$ & $\sqrt{ }$ \\
\hline Is humble and shares success & & $\sqrt{ }$ & & & & & & & & & & & & & & & & & \\
\hline $\begin{array}{l}\text { Promotes quality } \\
\text { relationships }\end{array}$ & & & & & & $\sqrt{ }$ & & & & & & & & $\sqrt{ }$ & $\sqrt{ }$ & & & $\sqrt{ }$ & \\
\hline Manages conflicts & & & & & $\sqrt{ }$ & $\sqrt{ }$ & & & & & & & & & & & & & \\
\hline $\begin{array}{l}\text { Accepts and takes } \\
\text { responsibility }\end{array}$ & & $\sqrt{ }$ & $\sqrt{ }$ & & & & & & & & & $\sqrt{ }$ & & & & & & & \\
\hline $\begin{array}{l}\text { Ability to process information } \\
\text { quickly }\end{array}$ & & & $\sqrt{ }$ & & & & & & & & & & & & & & & & \\
\hline $\begin{array}{l}\text { Ability to make decisions in } \\
\text { complex situations }\end{array}$ & & $\sqrt{ }$ & & & $\sqrt{ }$ & $\sqrt{ }$ & & & & & & & & & & & $\sqrt{ }$ & $\sqrt{ }$ & \\
\hline $\begin{array}{l}\text { Makes firm and quick } \\
\text { decisions }\end{array}$ & & $\sqrt{ }$ & & $\sqrt{ }$ & $\sqrt{ }$ & $\sqrt{ }$ & & & & & & $\sqrt{ }$ & & & $\sqrt{ }$ & & & & \\
\hline Scientific knowledge & & & & $\sqrt{ }$ & & & & & & $\sqrt{ }$ & & & & & $\sqrt{ }$ & $\sqrt{ }$ & $\sqrt{ }$ & & \\
\hline $\begin{array}{l}\text { Technical, relational, and } \\
\text { ethical skills }\end{array}$ & $\sqrt{ }$ & $\sqrt{ }$ & & & $\sqrt{ }$ & $\sqrt{ }$ & & & & $\sqrt{ }$ & & & & & $\sqrt{ }$ & $\sqrt{ }$ & & & $\sqrt{ }$ \\
\hline Continuing development & & & $\sqrt{ }$ & & & & & & & & & & & & & & & & $\sqrt{ }$ \\
\hline
\end{tabular}


Table 4. Results: Initial and lifelong training

\begin{tabular}{|c|c|c|c|c|c|c|c|c|c|c|c|c|c|c|c|c|c|c|c|}
\hline \multirow{2}{*}{ Results } & \multicolumn{19}{|c|}{ Study } \\
\hline & $\mathbf{1}$ & 2 & 3 & 4 & 5 & 6 & 7 & 8 & 9 & 10 & 11 & 12 & 13 & 14 & 15 & 16 & 17 & 18 & 19 \\
\hline Communication training & $\sqrt{ }$ & & & $\sqrt{ }$ & $\sqrt{ }$ & & $\sqrt{ }$ & $\sqrt{ }$ & $\sqrt{ }$ & & & & $\sqrt{ }$ & & & $\sqrt{ }$ & $\sqrt{ }$ & & \\
\hline Leadership education & & & $\sqrt{ }$ & & $\sqrt{ }$ & & $\sqrt{ }$ & $\sqrt{ }$ & $\sqrt{ }$ & & & & $\sqrt{ }$ & & $\sqrt{ }$ & $\sqrt{ }$ & $\sqrt{ }$ & & \\
\hline Teamwork training & & & $\sqrt{ }$ & & $\sqrt{ }$ & & $\sqrt{ }$ & $\sqrt{ }$ & $\sqrt{ }$ & & & & $\sqrt{ }$ & & $\sqrt{ }$ & $\sqrt{ }$ & $\sqrt{ }$ & $\sqrt{ }$ & \\
\hline Leadership training & & & $\sqrt{ }$ & & $\sqrt{ }$ & & $\sqrt{ }$ & $\sqrt{ }$ & $\sqrt{ }$ & & & & $\sqrt{ }$ & & $\sqrt{ }$ & $\sqrt{ }$ & $\sqrt{ }$ & $\sqrt{ }$ & \\
\hline
\end{tabular}

Table 5. Results: Leadership process

\begin{tabular}{|c|c|c|c|c|c|c|c|c|c|c|c|c|c|c|c|c|c|c|c|}
\hline \multirow{2}{*}{ Results } & \multicolumn{19}{|c|}{ Study } \\
\hline & 1 & 2 & 3 & 4 & 5 & 6 & 7 & 8 & 9 & 10 & 11 & 12 & 13 & 14 & 15 & 16 & 17 & 18 & 19 \\
\hline$\uparrow$ communication $=\uparrow$ leadership & $\sqrt{ }$ & $\sqrt{ }$ & $\sqrt{ }$ & $\sqrt{ }$ & $\sqrt{ }$ & & $\sqrt{ }$ & & $\sqrt{ }$ & $\sqrt{ }$ & & & & & $\sqrt{1}$ & $\sqrt{ }$ & $\sqrt{ }$ & $\sqrt{ }$ & $\sqrt{ }$ \\
\hline$\uparrow$ communication $=\downarrow$ errors & $\sqrt{ }$ & $\sqrt{ }$ & $\sqrt{ }$ & & & & & & & $\sqrt{ }$ & & & $\sqrt{ }$ & & & $\sqrt{ }$ & $\sqrt{ }$ & & \\
\hline$\uparrow$ communication $=\uparrow$ results & & $\sqrt{ }$ & $\sqrt{ }$ & & & & & & & & & & & & & $\sqrt{ }$ & $\sqrt{ }$ & & \\
\hline $\begin{array}{l}\uparrow \text { communication }=\uparrow \text { team } \\
\text { development }\end{array}$ & & $\sqrt{ }$ & & & & & & & $\sqrt{ }$ & & & & & & $\sqrt{ }$ & $\sqrt{ }$ & & & $\sqrt{ }$ \\
\hline $\begin{array}{l}\uparrow \text { communication }=\uparrow \text { quick } \\
\text { decision-making }\end{array}$ & $\sqrt{ }$ & & & & & & & & & & & & $\sqrt{ }$ & & & & & & \\
\hline$\uparrow$ communication $=$ correct decisions & & & & & & & & & & $\sqrt{ }$ & & & $\sqrt{ }$ & & & & & & \\
\hline$\uparrow$ leadership $=\downarrow$ errors & & & & & & & & & & $\sqrt{ }$ & & $\sqrt{ }$ & & & $\sqrt{ }$ & & & & $\sqrt{ }$ \\
\hline$\uparrow$ leadership $=\uparrow$ results & & & $\sqrt{ }$ & & & & & & & $\sqrt{ }$ & & $\sqrt{ }$ & & & $\sqrt{ }$ & & & & \\
\hline$\uparrow$ leadership $=\uparrow$ team dynamics & & & & & & & & & & $\sqrt{ }$ & & & & & $\sqrt{ }$ & & & & \\
\hline To clearly identify the leader & & & $\sqrt{ }$ & $\sqrt{ }$ & & & $\sqrt{ }$ & & & & & & $\sqrt{ }$ & & & & $\sqrt{ }$ & $\sqrt{ }$ & \\
\hline Initial briefing to set the strategy & & & $\sqrt{ }$ & & & & & & & & & & & $\sqrt{ }$ & & $\sqrt{ }$ & $\sqrt{ }$ & $\sqrt{ }$ & $\sqrt{ }$ \\
\hline To identify team members & & & $\sqrt{ }$ & & & & $\sqrt{ }$ & & & & & & $\sqrt{ }$ & & & $\sqrt{ }$ & & & \\
\hline $\begin{array}{l}\text { To delegate tasks based on } \\
\text { individual characteristics }\end{array}$ & & $\sqrt{ }$ & & $\sqrt{ }$ & & & & & & & & & $\sqrt{ }$ & & $\sqrt{ }$ & $\sqrt{ }$ & $\sqrt{ }$ & $\sqrt{ }$ & \\
\hline To use explicit, clear information & & & & $\sqrt{ }$ & & & $\sqrt{ }$ & $\sqrt{ }$ & & & $\sqrt{ }$ & $\sqrt{ }$ & & & & $\sqrt{ }$ & $\sqrt{ }$ & $\sqrt{ }$ & $\sqrt{ }$ \\
\hline $\begin{array}{l}\text { To use structured, two-way } \\
\text { communication }\end{array}$ & & & & $\sqrt{ }$ & & & $\sqrt{ }$ & & & & $\sqrt{ }$ & $\sqrt{ }$ & $\sqrt{ }$ & & $\sqrt{ }$ & & $\sqrt{ }$ & $\sqrt{ }$ & $\sqrt{ }$ \\
\hline $\begin{array}{l}\text { To confirm if information or } \\
\text { instruction is understood and } \\
\text { received }\end{array}$ & & & & $\sqrt{ }$ & & & & & & & $\sqrt{ }$ & & & & & $\sqrt{ }$ & & $\sqrt{ }$ & \\
\hline $\begin{array}{l}\text { Assertive leadership if a rapid } \\
\text { response is needed or in case of lack } \\
\text { of experience of team members }\end{array}$ & & & $\sqrt{ }$ & & & & & & & & $\sqrt{ }$ & & & & $\sqrt{ }$ & & $\sqrt{ }$ & & $\sqrt{ }$ \\
\hline Shared leadership whenever possible & $\sqrt{ }$ & & $\sqrt{ }$ & $\sqrt{ }$ & $\sqrt{ }$ & $\sqrt{ }$ & & & & & & & $\sqrt{ }$ & $\sqrt{ }$ & $\sqrt{ }$ & & $\sqrt{ }$ & & $\sqrt{ }$ \\
\hline $\begin{array}{l}\text { To limit the number of people } \\
\text { involved }\end{array}$ & & & $\sqrt{ }$ & & & & $\sqrt{ }$ & & & & & & & & $\sqrt{ }$ & & & $\sqrt{ }$ & \\
\hline $\begin{array}{l}\text { To encourage, motivate, and provide } \\
\text { positive feedback }\end{array}$ & & & $\sqrt{ }$ & & & & & & $\sqrt{ }$ & & & & & & & & $\sqrt{ }$ & $\sqrt{ }$ & $\sqrt{ }$ \\
\hline $\begin{array}{l}\text { To provide orientation and } \\
\text { reassurance }\end{array}$ & & & & & $\sqrt{ }$ & & & & & & & & & & & & & & $\sqrt{ }$ \\
\hline To promote organization & & & & & & & & & & & & & & & & $\sqrt{ }$ & $\sqrt{ }$ & & \\
\hline $\begin{array}{l}\text { To avoid task overload for team } \\
\text { members }\end{array}$ & & & & $\sqrt{ }$ & & & & & & & & & & & & & & & \\
\hline $\begin{array}{l}\text { To listen to the team and answer } \\
\text { questions }\end{array}$ & & & $\sqrt{ }$ & & & & & & & & $\sqrt{ }$ & & & & & & & & $\sqrt{ }$ \\
\hline Constant gathering of information & & & & $\sqrt{ }$ & & & & & & & $\sqrt{ }$ & & & & & & & $\sqrt{ }$ & \\
\hline Optimizes resources and constraints & & & & & & & & & & & & & & & & $\sqrt{ }$ & & & \\
\hline $\begin{array}{l}\text { The leader should not perform } \\
\text { technical tasks (if possible) }\end{array}$ & & & & $\sqrt{ }$ & & & & & & & & & & & & & $\sqrt{ }$ & & \\
\hline After-action debriefing & & & $\sqrt{ }$ & & $\sqrt{ }$ & $\sqrt{ }$ & & $\sqrt{ }$ & $\sqrt{ }$ & & & & & $\sqrt{ }$ & & $\sqrt{ }$ & & & $\sqrt{ }$ \\
\hline
\end{tabular}

Leaders play an important role in establishing an effective and organized communication within the team, ${ }^{[13,15,35]}$ and both nurses and physicians can assume a leadership role. ${ }^{[18]}$

Information should be as explicit as possible to avoid misinterpretations ${ }^{[4,6,11,13,20,21,26,27]}$ and say the most important things first. ${ }^{[27]}$ For example, when demonstrating how to administer medication, the leader should address the team member by his/her name, and clearly state the name, dose, method, and schedule of administration of the medication.

Communication should be a two-way process ${ }^{[6,11,20-22,24]}$ between the leader and the team members, and the sender should make sure that the receiver is listening and providing feedback, and that the information or instruction has been received and understood. ${ }^{[4,6,20]}$ 
Communication should be preferably structured using the ABCDE (Airway, Breathing, Circulation, Disability, Exposure) approach, ${ }^{[35]}$ while the SBAR strategy should be used in the initial briefing and when providing information in person or over the phone. ${ }^{[11,37]}$

Hostile behaviors that may inhibit communication should be avoided. ${ }^{[15]}$

Several attributes of good leaders have been identified, namely the ability to communicate well and consistently; appropriate knowledge, motivation, and influencing skills; confidence; and the ability to maintain a balance within the team. ${ }^{[14]}$ Leaders should be role models and lead by example, guiding the team and making substantiated and quick decisions. ${ }^{[14,17]}$

The choice of a leader is an important step in this process ${ }^{[18]}$ and should be based on experience and professional status, ${ }^{[15]}$ without neglecting professional experience and reflective practice, ${ }^{[16]}$ given that the lack of experience is a clear barrier to an effective leadership. ${ }^{[6,19]}$ In this sense, appointing physicians to leadership roles just because they are physicians can be a mistake. ${ }^{[6]}$ Leaders who have more than three years of experience are more effective leaders than those who have only one year of experience, and the vast majority of resident physicians (who are less experienced) feel inadequately trained to lead a team in an emergency situation. ${ }^{[25]}$ Leaders should also be chosen based on characteristics such as humility and the ability to share successes ${ }^{[14]}$ assume responsibility, ${ }^{[1-15]}$ and solve conflicts through negotiation, both within the team and with patients and/or family. ${ }^{[15-17]}$

The leadership strategy should be adjusted according to the situation, which may require a more "autocratic" or "participative" leadership. ${ }^{[13,16]}$ When a situation requires a swift intervention, or when team members are less experienced, the leader should be more assertive. However, when the situation runs smoothly, and team members show adequate experience and autonomy, the leader can adopt a shared and participative model of leadership. ${ }^{[13,17,32]}$ In any case, leadership should be exerted through knowledge, safety, and experience, ${ }^{[17]}$ and never through mere authoritarianism or intimidation. ${ }^{[18]}$ Team consensus is particularly essential when dealing with ethical dilemmas (e.g., the decision to stop resuscitation efforts).

Leaders should have in-depth knowledge of the team in order to be able to adjust their leadership style ${ }^{[14,17]}$ because leaders can only put the right person in the right place ${ }^{[18]}$ and delegate tasks properly if they are aware of each member's potential.

One of the leader's key responsibilities is to pay attention to the environment and limit the number of people present in the area to reduce the risk of miscommunication and distraction. ${ }^{[11,26]}$

Immediately after the team intervention (or as soon as possible), the leader should meet with all team members for a moment of structured reflection or debriefing. ${ }^{[4,11,15-18,27,29]}$ The key purpose of debriefing is the team's continuous improvement, so it should start with the sharing and analysis of individual feelings, followed by the discussion of positive aspects and aspects to be improved in future interventions. During the debriefing, the leader should connect theory and practice and, if necessary, identify topics for individual and collective study and training.

\section{Limitations}

This SLR had some limitations, namely the lack of literature on communication and leadership in emergency situations, and the type of studies found. This SLR included qualitative studies (the majority of the articles), as well as observational studies, theoretical end integrative reviews and opinion articles. Quantitative studies used small, non-random samples. Although a set of recommendations was put forward, they should be interpreted and implemented with caution, taking into account the low level of evidence supporting them.

\section{CONCLUSIONS AND RECOMMENDATIONS FOR PRACTICE}

The purpose of this SLR was to identify communication and leadership best practices in emergency situations. Nineteen articles were identified and analyzed to extract data on three dimensions: leader's characteristics, initial and lifelong training, and leadership process.

Despite the above-mentioned limitations, the existing evidence allows putting forward the following recommendations:

- Team members should receive regular education and training on teamwork;

- Team members should receive regular education and training on communication and leadership in emergency situations;

- The leader should have strong relational and communication skills, a solid scientific, technical, and ethical knowledge, experience in clinical practice, and leadership training;

- The leader should be clearly identified prior to patient care delivery;

- The leader should know all team members, as well as their skills and limitations;

- If possible, an initial briefing should be held to set the 
strategy and delegate tasks to team members, taking into account their individual characteristics;

- Ideally, the leader should not be involved in activities other than leading;

- Information should be explicit and clear;

- Communication should be a two-way, structured (ABCDE, SBAR) process;

- The leader should communicate instructions assertively when a rapid response is necessary or when team members are less experienced;

- If possible, the leader should develop shared leadership, particularly when dealing with ethical dilemmas;

- The leader should confirm that the information was received and understood;

- The leader should limit the number of people present in the area;

- The leader should avoid overloading team members with multiple tasks;

- The leader should encourage, motivate, and provide positive feedback to team members;

- The leader should listen to team members and answer their questions;

- The leader should continuously gather information, optimize resources, and manage constraints;

- In case of deviations, the leader should provide prompt guidance and promote organization;

- Immediately after the critical event (or as soon as possible), the leader should meet with the team to reflect on the intervention (debriefing), and identify and analyze the team members' feelings, positive aspects of the intervention, and aspects to be improved.

There is still much work to be done on this topic. The implementation of these recommendations should be followed by the development of studies using valid and reliable instruments to analyze the associated outcomes. Future research will contribute to the assessment of each recommendation.

\section{FOUNDING SOURCES}

This systematic review was carried out within the scope of the SimuCarePro project, an ERASMUS+ KA2 project funded with the support of the European Union. Project Reference: 15PS0009 (2015-1-BE01-KA203-013218).

\section{CONFlicts OF InTEREST Disclosure}

\section{REFERENCES}

[1] Kilner E, Sheppard LA. The role of teamwork and communication in the emergency department: a systematic review. International Emergency Nursing. 2010; 18: 127-137. PMid: 20542238. https://doi.org/10.1016/j.ienj.2009.05.006

[2] Shankar K, Bhatia B, Schuur J. Toward patient-centered care: a systematic review of older adults' views of quality emergency care. Annals of Emergency Medicine. 2014; 6: 529-550. PMid: 24051211. https://doi.org/10.1016/j.annemergmed.2013.07.509

[3] Barati O, Sadeghi A, Khammarnia M, et al. A qualitative study to identify skills and competency required for hospital managers. Electronic Physician. 2016; 8(6): 2458-2465. https://doi.org/10.1 $9082 / 2458$

[4] Azinhaga A. Trabalho em equipa em contexto de emergência: perceção dos enfermeiros e dos médicos num serviço de urgência médico-cirúrgico. (Master's Dissertation). 2014; Escola Superior de Enfermagem de Coimbra. Coimbra. Available from: http: //repositorio.esenfc.pt/?url=3hlthbn3

[5] Hunziker S, Tschan F, Semmer NK, et al. Human factors in resuscitation: lessons learned from simulator studies. Journal of Emergencies, Trauma, and Shock. 2010; 3: 389-394. PMid: 21063563. https://doi.org/10.4103/0974-2700.70764

[6] Andersen P, Jensen M, Lippert A, et al. Identifying non-technical skills and barriers for improvement of teamwork in cardiac arrest teams. Resuscitation. 2010; 81(6): 695-702. https ://doi .org/10 $.1016 / j$.resuscitation. 2010.01 .024

[7] Rosenman E, Shandro J, Ilgen J, et al. Leadership training in health care action teams: a systematic review. Acad Med. 2014; 89: 1295-
1306. PMid: 25006708. https://doi.org/10.1097/ACM. 0000 000000000413

[8] Manning J. The influence of nurse manager leadership style on staff nurse work engagement. J Nurs Adm. 2016; 46: 438-443. PMid: 27496584.

[9] Menaker R. Leadership strategies: achieving personal and professional success. J Med Pract Manage. 2016; 31: 336-339. PMid: 27443052.

[10] Flowerdew L, Brown R, Russ S, et al. Teams under pressure in the emergency department: an interview study. Emerg Med J. 2012; 29: e2. PMid: 22186010. https://doi.org/10.1136/emerme d-2011-200084

[11] Price JW, Applegarth O, Vu M, et al. Code blue emergencies: a team task analysis and educational initiative. Canadian Medical Education Journal. 2012; 3: e4-e20. PMid: 26451171.

[12] Joanna Briggs Institute (Eds). Joanna Briggs Institute reviewers' manual. 2014. ISBN 978-1-9206884-11-2.

[13] Montezeli JH, Peres AM, Bernardino E. Nurse management skills required at an emergency care unit. Journal of Research Fundamental Care Online. 2013; 5: 245-252. https://doi.org/10.9789/21 $75-5361.2013 v 5 n 3 p 245$

[14] Linton J, Farrell MJ. Nurses' perceptions of leadership in an adult intensive care unit: a phenomenology study. Intensive and Critical Care Nursing. 2009; 25: 64-71. PMid: 19131249. https: //doi.org/10.1016/j.iccn.2008.11.003

[15] Cole E, Crichton N. The culture of a trauma team in relation to human factors. Journal of Clinical Nursing. 2006; 15(10): 1257-1266. https://doi.org/10.1111/j.1365-2702.2006.01566.x 
[16] Cathcart EB, Greenspan M, Quin M. The making of a nurse manager: the role of experiential learning in leadership development. Journal of Nursing Management. 2010; 18(4): 440-447. https: //doi.org/10.1111/j.1365-2834.2010.01082.x

[17] Araszewski D, Bolzan MB, Montezeli H, et al. O exercício da liderança sob a ótica de enfermeiros de pronto socorro. Cogitare Enfermagem. 2014; 19(1): 41-47. https://doi.org/10.5380/ce .v19i1.35933

[18] Clements A, Curtis K, Horvat L, et al. The effect of a nurse team leader on communication and leadership in major trauma resuscitations. International Emergency Nursing. 2015; 23(1): 3-7. https ://doi.org/10.1016/j.ienj.2014.04.004

[19] Cooper S, O’Carroll J, Jenkin A, et al. Collaborative practices in unscheduled emergency care: role and impact of the emergency care practitioner-quantitative findings. Emergency Medicine Journal. 2007; 24(9): 630-633. https ://doi.org/10.1136/emj . 2007.0 48058

[20] Kemper PF, van Noord I, de Bruijne M, et al. Development and reliability of the explicit professional oral communication observation tool to quantify the use of non-technical skills in healthcare. BMJ Quality \& Safety. 2013; 22: 586-595. PMid: 23412933. https://doi.org/10.1136/bmjqs-2012-001451

[21] Deitchman S. Enhancing crisis leadership in public health emergencies. Disaster Medicine and Public Health Preparedness. 2013; 7(5): 534-540. https://doi.org/10.1017/dmp. 2013.81

[22] Leach LS, Mayo AM. Rapid response teams: qualitative analysis of their effectiveness. American Journal of Critical Care. 2013; 22 198-210. PMid: 23635929. https://doi.org/10.4037/ajcc20 13990

[23] Speck RM, Jones G, Barg FK, et al. Team composition and perceived roles of team members in the trauma bay. Journal of Trauma Nursing: The Official Journal of the Society of Trauma Nurses. 2012; 19: 133-138. PMid: 22955707. https ://doi.org/10.1097/JTN. Ob $013 e 318261 d 273$

[24] Silva DS, Bernardes A, Gabriel CS, et al. A liderança do enfermeiro no contexto dos serviços de urgência e emergência. Revista Eletrónica de Enfermagem. 2014; 16: 211-219. https://doi.org/10.521 6/ree.v16i1.19615

[25] Manser T. Teamwork and patient safety in dynamic domains of healthcare: a review of the literature. Acta Anaesthesiologica Scandinavica. 2009; 53(2): 143-151. PMid: 19032571. https://doi.org/10.1 111/j.1399-6576.2008.01717.x

[26] Bristowe K, Siassakos D, Hambly H, et al. Teamwork for clinical emergencies: interprofessional focus group analysis and triangulation with simulation. Qualitative Health Research. 2012; 22(10): $1383-$ 1394. PMid: 22811304. https://doi.org/10.1177/10497323 12451874

[27] Lynch A, Cole E. Human factors in emergency care: the need for team resource management. Emergency Nurse. 2006; 14: 32-35.
PMid: 16739445. https://doi.org/10.7748/en2006.05.14 .2.32.c1226

[28] Martins JC. Atuação do enfermeiro no setor de urgências: gestão para o desenvolvimento de competências. In: Malagutti, William; Caetano, Karen (org) - Gestão do serviço de enfermagem no mundo globalizado; 2009. 175-189 p.

[29] Flowerdew L, Brown R, Vincent C, et al. Identifying nontechnical skills associated with safety in the emergency department: a scoping review of the literature. American College of Emergency Physicians. 2011; 59: 386-394.

[30] Meier C. Importance of good teamwork in urgent care services. Emergency Nurse. 2014; 22: 32-36. PMid: 25369970. https: //doi.org/10.7748/en.22.7.32.e1312

[31] Martins J, Mazzo A, Baptista R, et al. The simulated clinical experience in nursing education: a historical review. Acta Paulista de Enfermagem. 2012; 25: 619-625. https ://doi.org/10.1590/S0 103-21002012000400022

[32] Trentham B, Andreoli A, Boaro N, et al. SBAR: a shared structure for effective team communication. Toronto Rehabilitation Institute and the Canadian Patiet Safety Iwtitutee. 2010. PMid: 20692543.

[33] Castelao EF, Boos M, Ringer C, et al. Effect of CRM team leader training on team performance and leadership behavior in simulated cardiac arrest scenarios: a prospective, randomized, controlled study. BMC Med Educ. 2015; 15: e116. PMid: 26205962. https://doi.org/10.1186/s12909-015-0389-z

[34] Martins J, Baptista R, Coutinho V, et al. Self-confidence for emergency intervention: adaptation and cultural validation of the selfconfidence scale in nursing students. Revista Latino-Americana de Enfermagem. 2014; 22: 554-561. https ://doi.org/10.1590/01 04-1169.3128.2451

[35] Foronda C, Liu S, Bauman E. Evaluation of simulation in undergraduate nurse education: an integrative review. Clinical Simulation in Nursing. 2013; 9: e409-e416.

[36] Figueroa F, Moftakhar Y, Dobbins L, et al. Trauma boot camp: a simulation-based pilot study. Cureus. 2013; 8: e463.

[37] Baker V, Cuzzola R, Knox C, et al. Teamwork education improves trauma team performance in undergraduate health professional students. Journal of Educational Evaluation for Health Professions. 2015; 12: 1-6. https://doi.org/10.3352/jeehp. 2015.12.36

[38] Greif R, Lockey A, Conaghan P, et al. European Resuscitation Council guidelines for resuscitation 2015 section 10: education and implementation of resuscitation. Resuscitation. 2015; 95: 288-301.

[39] Wong A, Wing L, Weiss B, et al. Coordinating a team response to behavioral emergencies in the emergency department: a simulationenhanced interprofessional curriculum. West J Emerg Med. 2015; 16 : 859-865. PMid: 26594279. https ://doi.org/10.5811/westje m. 2015.8.26220 